\title{
Canine hypertrophic osteopathy associated with extra-thoracic lesions
}

\author{
Osteopatia hipertrófica canina associada com lesões extratorácicas
}

\author{
Selwyn Arlington Headley ${ }^{1}$ Eduardo Alcântara Ribeiro ${ }^{2}$ \\ Gustavo José Von G. dos Santos $^{3}$ Carlos Maia Bettini ${ }^{4}$ Ewaldo Mattos Júnior ${ }^{5}$
}

\begin{abstract}
Canine hypertrophic osteopathy is described in a dog that presented extra-thoracic lesions, mainly in the liver. Hepatic lesions were characterized by necrosis, hemorrhage, severe hydropic degeneration of centrolobular hepatocytes, proliferation of epithelial cells of bile ducts, and mild biliary stasis. The disease syndrome was diagnosed based on clinical signs, radiological evaluation, and inspection of macerated bones.
\end{abstract}

Key words: hypertrophic osteopathy, dog, pathology, radiology, liver

\section{RESUMO}

Osteopatia hipertrófica canina é descrita em um cão que apresentou lesões extratorácicas, principalmente no fígado. As alterações hepáticas foram caracterizadas por necrose, hemorragia, degeneração hepatocelular severa, proliferação das células epiteliais dos ductos biliares e estase biliar. $O$ diagnóstico desta síndrome foi baseado nos sinais clínicos, a avaliação radiológica e a inspeção dos ossos macerados.

Palavras-chave: osteopatia hipertrófica, cão, patologia, radiologia, fígado.

Hypertrophic osteopathy (also known as hypertrophic pulmonary osteopathy and metaphyseal osteopathy) is a disease syndrome observed mainly in man and dogs (PALMER, 1993; LENEHAN \&
FETTER, 2003). The disease has also been described in the horse, cow, sheep, cat, and domestic fowl (REICHMANN et al., 2001; LENEHAN \& FETTER, 2003).

Canine hypertrophic osteopathy $(\mathrm{CHO})$ is characterized by bilateral, diffuse periosteal osteophytosis secondary to chronic inflammatory or neoplastic intrathoracic lesions, but in rare cases, extrathoracic disease processes have been described (PALMER, 1993; JONES et al., 1997; LENEHAN \& FETTER, 2003). Most cases of CHO occur in animals that presented intrathoracic lesions such as pulmonary abscesses (REICHMANN et al., 2001), primary lung tumors, pulmonary metastases and tuberculosis, dirofilariasis, bacterial endocarditis, and spirocercosis (PALMER, 1993; LENEHAN \& FETTER, 2003). Extrathoracic alterations previously associated with $\mathrm{CHO}$ include hepatic adenocarcinoma and primary neoplasms of the urinary bladder (LENEHAN \& FETTER, 2003). Although there is no definite breed predisposition, Boxers and other large breed dogs are more frequently affected (LENEHAN \& FETTER, 2003). Older dogs (more than 8.5 years-of-age) have a tendency to present $\mathrm{CHO}$ relative to their younger counterparts (ALLAN, 1998; LENEHAN \& FETTER, 2003).

Clinically, there is bilateral, symmetrical, and nonedematous soft tissue swelling affecting primarily

\footnotetext{
${ }^{1}$ Laboratório de Patologia Veterinária, Hospital Veterinário, Bloco II, Centro Universitário de Maringá (CESUMAR), Av Guedner, 1610. 87050-390, Maringá, PR, Brasil. E-mail: headleysa@cesumar.br Autor para correspondência.

${ }^{2}$ Departamento de Radiologia e Clínica Médica de Pequenos Animais, Faculdade Integrado (INTEGRADO), Campo Mourão, PR, Brasil.

${ }^{3}$ Departamento de Anestesiologia e Clínica Médica de Pequenos Animais, INTEGRADO, Campo Mourão, PR, Brasil.

${ }^{4}$ Departamento de Radiologia e Clínica Médica de Pequenos Animais, CESUMAR, Maringá, PR, Brasil.

${ }^{5}$ Médico Veterinário, INTEGRADO, Campo Mourão, PR, Brasil..
} 
the distal extremities of all four limbs (LENEHAN \& FETTER, 2003). Affected joints are normally warm, painful, and the animal shows marked reluctance to movement (BORGES et al., 1993; ALLAN, 1998; JONES et al., 1997). Lesions of $\mathrm{CHO}$ are more severe at the radius, ulna, tibia, and metacarpus, while upper limbs and phalanges are less affected (PALMER, 1993). Radiographic evaluation of these alterations is diagnostic for CHO (ALLAN, 1998; LENEHAN \& FETTER, 2003); while the extent of these lesions is best demonstrated in macerated specimens of the affected limb (PALMER, 1993). Radiographically, CHO is characterized by bilateral, symmetrical, and generalized periosteal proliferation of long bones of the appendicular skeleton (LENEHAN \& FETTER, 2003). Hematological alterations (low erythrocyte count, but normal total white blood cells) have also been described (FILGUEIRAS et al., 2002).

This article describes a case of canine hypertrophic osteopathy in a two year-old, male mongrel dog. This report is important because the animal did not present any intrathoracic or pulmonary alterations.

A two-year-old, male, unvaccinated mongrel dog with a history of jaundice, vomiting, melena, and vomiting during a period of 60 days was submitted to the Veterinary Teaching Hospital, Faculdade Integrado, Campo Mourão, PR, Brazil. According to the owner, the animal showed hyporexia, marked increase in volume of the distal extremities of all members, and locomotion difficulties. Routine clinical, physical, laboratorial, and radiological evaluations were performed. The animal was sacrificed to relieve suffering and routine necropsy was performed soon after death. Selected tissues (lung, heart, liver, brain, and kidney) were fixed in $10 \%$ formalin solution and processed for routine histopathological evaluation; the affected members were prepared for maceration.

Clinically, the dog was cachectic, moderately dehydrated $(6 \%)$, with icteric mucus membranes (oral, ocular and genital), and demonstrated severe pain when standing and during locomotion. There was bilateral and symmetric swelling of the metacarpus and metatarsus. Radiological evaluation and macerated bones of both the hind and forelimbs revealed irregular, proliferative, symmetrical and bilateral periosteal reactions throughout the medial and distal diaphysis of the metacarpus and metatarsus (Figure 1). Similar proliferative alterations were observed on the phalanges, the carpal and tarsal bones, and the distal third of the tibia. Additionally, there was marked increase in the size of adjacent soft tissues. Radiographical alterations were not observed within the thoracic cavity.

All laboratory values were compared with reference data elsewhere (COLES, 1986; JAIN, 1993). A discrete hypoalbuminemia (1.9 $\mathrm{g} \mathrm{dl}^{-1}$; normal, 6.9$\left.7.8 \mathrm{~g} \mathrm{dl}^{-1}\right)$, mild elevation of alanine aminotransferase, ALT (32 $\mathrm{U}^{-1}$; normal, 8-24), and reduction of calcium $\left(8 \mathrm{mg} \mathrm{dl}^{-1}\right.$; normal, $\left.10 \mathrm{mg} \mathrm{dl}^{-1}\right)$ were observed through biochemical serum analysis. Hematological evaluation revealed a reduction in the number of erythrocytes (3.29 million $\mathrm{mm}^{-3}$; normal, 5.5-8.5 million $\mathrm{mm}^{-3}$ ); hemoglobin $\left(6.4 \mathrm{gd} \mathrm{l}^{-1}\right.$; normal, $\left.12-18 \mathrm{~g} \mathrm{dl}^{-1}\right)$, and packed cell volume (19.7\%; normal, $37-55 \%)$. The total count for white blood cells was within the lower acceptable limit: leucocytes $\left(6,000 \mathrm{~mm}^{-3}\right.$; normal, $\left.6,000-17,000 \mathrm{~mm}^{-3}\right)$, eosinophils $\left(60 \mathrm{~mm}^{-3}\right.$; normal, $\left.100-1,250 \mathrm{~mm}^{-3}\right)$, lymphocytes $\left(1,080 \mathrm{~mm}^{-3}\right.$; normal, $\left.1,000-4,800 \mathrm{~mm}^{-3}\right)$, monocytes $\left(300 \mathrm{~mm}^{-3}\right.$; normal, $\left.150-1,350 \mathrm{~mm}^{-3}\right)$, immature neutrophils, $\left(180 \mathrm{~mm}^{-3} ;\right.$ normal, $\left.0-3 \mathrm{~mm}^{-3}\right)$, and mature neutrophils $\left(4,380 \mathrm{~mm}^{-3}\right.$; normal, $\left.60-77 \mathrm{~mm}^{-3}\right)$.

Marked gross findings include moderate to severe jaundice of mucosal membranes and subcutaneous tissue, moderate ascites and generalized enlargement of regional lymph nodes. The distal extremities of all members were severely increased with marked edema of subcutaneous tissue. The liver surface was markedly and diffusedly nodular; cut sections revealed marked hemorrhage and congestion, associated with various differentsized, irregular nodular areas diffusedly distributed throughout the organ. The renal capsular surface was markedly irregular with several small $(0.5-1 \mathrm{~cm})$, whitish, irregular distributed areas. There was mild pulmonary edema. Severe histopathological alterations were restricted to the liver and kidneys. There was marked, multifocal, necrotic and hemorrhagic hepatitis, severe hydropic degeneration of centrolobular hepatocytes; moderate to severe megalocytosis with severe and multifocal periportal proliferation of epithelial cells of bile ducts, mild biliary stasis and sparing of periportal hepatocytes. Renal alterations included chronic multifocal interstitial nephritis, degeneration of renal tubules associated with intratubular hyaline casts.

The clinical, pathological, and radiological alterations of the distal extremities observed in this dog are consistent with canine hypertrophic osteopathy (CHO) as previously described (PALMER, 1993; JONES et al., 1997; LENEHAN \& FETTER, 2003). However, in the present report, there were no severe pulmonary alterations; similar cases have also been described (PALMER, 1993; LENEHAN \& FETTER, 2003). Recently, similar skeletal lesions 


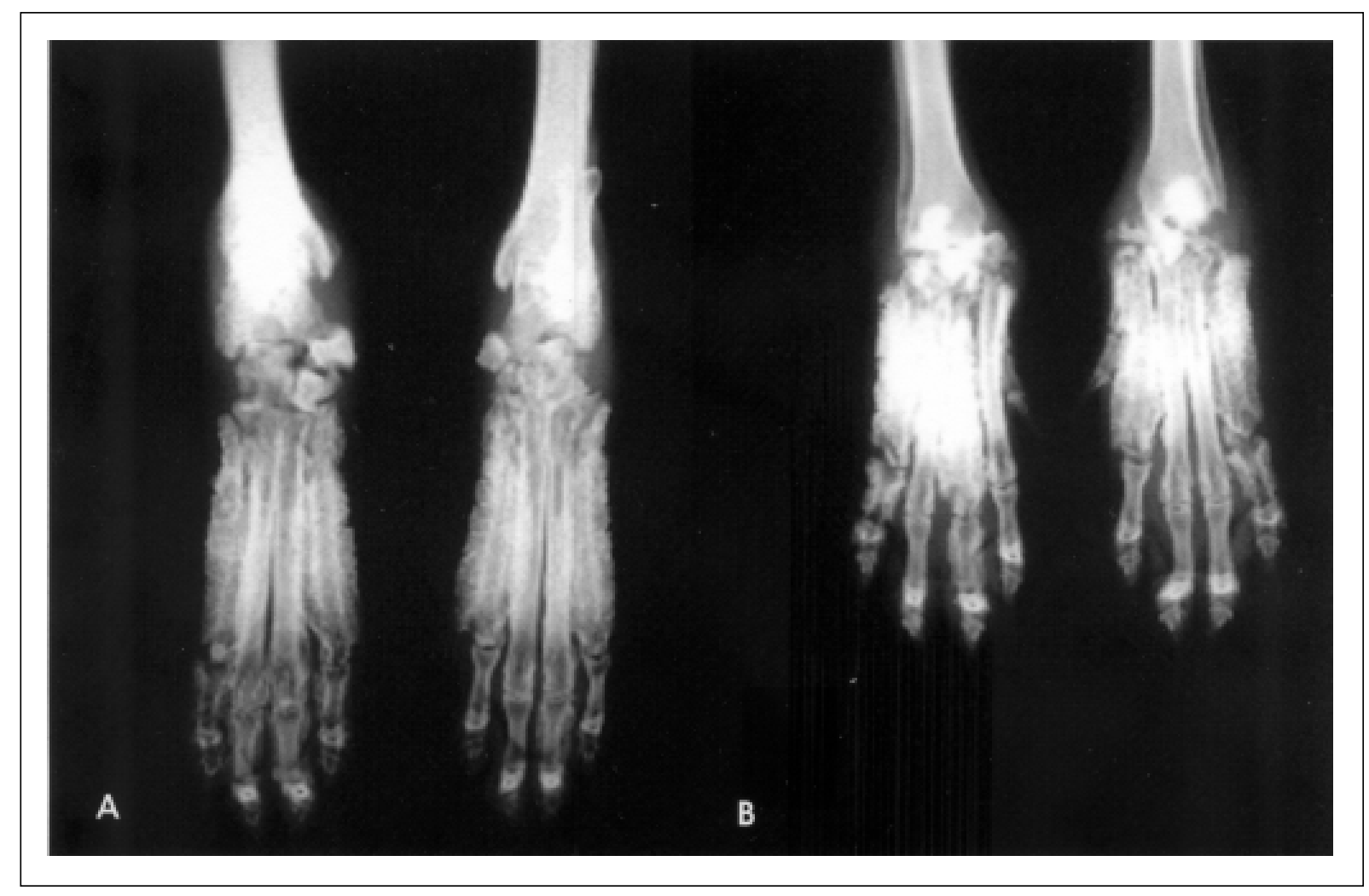

Figure 1 - Canine hypertrophic osteopathy, radiograph; (A) There is severe irregular periosteal reaction at the metatarsus, tarsus, and the distal extremities of the tibia and fibula with edema of adjacent soft tissue; (B) Similar alterations are shown at the metacarpus and carpus.

were observed in dogs and coyotes experimentally infected with Hepatozoon americanum (PANCIERA et al., 2000); so this parasitic disease could be considered as differential diagnostic in cases of $\mathrm{CHO}$.

The pathogenesis of $\mathrm{CHO}$ has not been fully elucidated. There are several theories but none clearly reflects the clinical manifestations of $\mathrm{CHO}$ (PALMER, 1993). The neurogenic theory is widely accepted, indicating that these skeletal alterations are the result of nervous reflex impulses that arise from the intrathoracic lesion, traveling via the vagus nerve and finally producing vasomotor disturbances in the extremities (PALMER, 1993; LENEHAN \& FETTER, 2003). Additionally, stimulation of vasopharyngeal and vagus nerve endings in vascularized tissues have been related to extrathoracic cases of CHO (LENEHAN \& FETTER, 2003), and there is also a hormonal and a hypoxia shunting-related theory (PALMER, 1993). The development of $\mathrm{CHO}$ in this case of hepatic dysfunctions could be related to a combination of hypoxia as observed in the liver and neurogenic mechanisms.

Considering the age of the animal and the anatomic location of the principal lesion, the development of $\mathrm{CHO}$ in this dog is extremely atypical. $\mathrm{CHO}$ is not frequently observed in dogs that are less than 8.5 years-of-age (LENEHAN \& FETTER, 2003); this dog was only two years old. CHO is more frequently described in association with intrathoracic relative to extrathoracic lesions (PALMER, 1993; LENEHAN \& FETTER, 2003); the alterations observed in this dog were predominantly extrathoracic. In this study, pathological alterations were mainly hepatic demonstrating clinical manifestations typical of severe liver dysfunction. These hepatic alterations observed in this dog could be related to acute and chronic aflatoxicosis, infectious viral hepatitis, or other conditions that induce hypoxia (PALMER, 1993). Liver disease previously related to $\mathrm{CHO}$ include, cirrhosis (PALMER, 1993) and hepatic adenocarcinoma (LENEHAN \& FETTER, 2003); but no descriptions of $\mathrm{CHO}$ has been found related to the alterations found in this case.

The laboratory results indicative of hepatic dysfunction (hypoalbuminemia and mild elevation of ALT), were confirmed histopathologically, and could

Ciência Rural, v.35, n.4, jul-ago, 2005. 
be related to the cachectic state of this animal. Serum alterations of ALT are specific for hepatic disease in dogs, being a manifestation of enzyme lost due to damaged hepatocytes (COLES, 1986). Hypoalbuminemia has been related to decreased synthesis, intestinal, cutaneous, and urine loss, and increased catabolism of albumin (COLES, 1986: JAIN, 1993); in this case, hypoalbuminemia should be related to reduce protein synthesis associated with marked hepatic necrosis. Biochemical values for urea, creatinine, GGT, alkaline phosphatase, and phosphorus were unchanged; similar results have been described (FILGUEIRAS et. al., 2002). So probably the metabolism of these enzymes and minerals is not directly affected in cases of $\mathrm{CHO}$. Additionally, the white blood cells of this dog were observed within the lower acceptable limit; this may be a manifestation of reduced immunological response due to reduced protein intake as demonstrated by the deplorable body condition of the animal associated with reduced protein synthesis by the affected liver.

\section{REFERENCES}

ALLAN, G. Radiographic signs of joint disease. In: THRALL, D.E. (ed). Textbook of veterinary diagnostic radiology. 3.ed. Philadelphia : Saunders, 1998. Cap.16, p.169-188.
BORGES A.P.B. et al. Osteopatia pulmonar em cão: descrição de um caso. Revista Brasileira de Medicina Veterinária, v.15, n.2. p.53-55, 1993.

COLES, E.H. Veterinary clinical pathology. 4.ed. Saunders: Philadelphia, 1986. p.486.

FILGUEIRAS, R.R. et al. Osteopatia hipertrófica em cãorelato de caso. Clínica veterinária, n.36, p.28-31, 2002.

JAIN, N.C. Essentials of veterinary hematology. Philadelphia : Lea \& Febiger, 1993. 417p.

JONES, T.C.H. et al. Veterinary pathology. 6. ed. Baltimore: Lippincott Williams \& Wilkins, 1997. p. 926-927.

LENEHAN, T.M.; FETTER, A.W. Hypertrophic osteopathy. In: NEWTON, C.D., NUNAMAKER, D.M. Textbook of small animal orthopedics. Baltimore : Lippincott. Consulted on 16 May, 2003. On line. Available at http://cal.vet.upenn.edu/ saortho/

PALMER, N. Bone and joints. In: JUBB, K.V.C. et al. The pathology of domestic animals. 4.ed. Diego : Academic, 1993. V.1, cap.1, p.1-181.

PANCIERA, R.J. et al. Skeletal lesions of canine hepatozoonosis caused by Hepatozoon americanum. Veterinary Pathology, v.37, p.225-230, 2000.

REICHMANN, P. et al. Osteopatia hipertrófica em eqüino: relato de caso. Rev Educ Contin, v.4, p.41-45, 2001. 